\title{
Working with legal pluralism: widowhood, property inheritance and poverty alleviation in urban Senegal
}

Article

Accepted Version

Evans, R. (2015) Working with legal pluralism: widowhood, property inheritance and poverty alleviation in urban Senegal. Gender and Development, 23 (1). pp. 77-94. ISSN 1364-9221 doi: https://doi.org/10.1080/13552074.2015.1013678 (special issue: Working on gender equality in urban areas) Available at https://centaur.reading.ac.uk/39169/

It is advisable to refer to the publisher's version if you intend to cite from the work. See Guidance on citing.

To link to this article DOI: http://dx.doi.org/10.1080/13552074.2015.1013678

Publisher: Taylor \& Francis

All outputs in CentAUR are protected by Intellectual Property Rights law, including copyright law. Copyright and IPR is retained by the creators or other copyright holders. Terms and conditions for use of this material are defined in the End User Agreement.

www.reading.ac.uk/centaur 
Central Archive at the University of Reading

Reading's research outputs online 


\section{Working with legal pluralism: widowhood, property inheritance and poverty alleviation in urban Senegal}

\section{Ruth Evans}

This article explores the role of women's inheritance and ownership of property in urban Senegal. It shows how being able to inherit and own property promotes the economic and emotional security of widows and their children in urban areas, and discusses the challenges posed by legal pluralism in working on poverty alleviation and social protection in the city.

Key words: property rights; inheritance practices; legal pluralism; widows; social protection; Senegal

\section{Introduction}

In urban areas, poor people are likely to live in low-quality housing without formal property tenure (Payne et al. 2008). Property represents a place to live, but also serves as security which underpins many other important aspects of making a livelihood, including providing a workplace for informal sector work, collateral to obtain agricultural inputs or loans for businesses, and rental opportunities to gain income in the absence of other income-generating opportunities (Chant, 2013).

In patriarchal societies in the global South, women commonly live as daughters and wives in households which are owned or rented by men, and property is usually inherited through the male line (Bass and Sow, 2006). Widowhood may mean losing your home, and with it, your economic security. Women's property rights are, thus, an extremely important element in making widows secure. Increased control of land, property and other assets and resources by women and other marginalised groups is thought to break poverty cycles and interrupt the intergenerational transmission of poverty (Cooper 2012).

Recent legal reforms and development initiatives in many African countries have sought to promote women's equal access to land and property ownership, as a means of alleviating poverty and reducing gender inequalities. However, in many sub-Saharan African countries, there is a complex environment surrounding widows' position, which means civil law reforms may not offer a sole solution. The complexity comes from religious and customary inheritance practices which co-exist in a plural legal framework alongside civil law.

This article draws on recent qualitative research to explore women's property rights in urban Senegal, and in particular the situation of Serer widows in Dakar. The article highlights how women's property rights in urban Senegal are both constrained and enabled by religious and customary inheritance practices, and the country's plural legal framework. It also focuses on policy and practice responses to the issues of inheritance, poverty alleviation and social protection which widows in Dakar face. The research formed part of a wider study on inheritance, access to resources and poverty in Serer families in Senegal, which was conducted in 2011-12 (1).

\section{Life in Dakar: migration, poverty and gender inequality}

The research discussed here centred on widows in low-income districts and suburbs [banlieues] of Dakar, including Médina, Guédiawaye, Keur Massar and Yeumbeul.

(C) Ruth Evans 3/2/15. Article in press, Gender and Development, March 2015 issue, 'Working on Gender Issues in Urban Areas'. 
A quarter of the population of Senegal, and over half of all urban residents, now live in Dakar and its surrounding suburbs (ANSD 2013a). Dakar was founded around 1857 as the main administrative capital for French West Africa (Piga 2002). The post-colonial era brought about administrative reorganisation, the establishment of new districts, suburbs and provision of social housing, accompanied by forced evictions and the demolition of shantytowns in central Dakar. The city continues to grow today, and both formal and informal settlements have developed to house a population which was 3 million in 2011, and is projected to increase at a rate of 4.45 per cent in the decade 2010-20 - that is, by more than 100,000 inhabitants annually - in common with other major West African cities (UN-Habitat, $2014,101 \& 103)$.

Médina, one of the research locations, is one of the city's oldest high-density districts in central Dakar, established to re-house the indigenous African population evicted from Plateau (the European commercial and administrative centre) and to restrict the population's mobility and limit the spread of epidemics (Piga, 2002). The large urban areas of Guédiawaye (another of the research locations) and neighbouring Pikine were created during the two decades from 1950, in order to clear shantytowns and reduce congestion in Dakar city centre (Piga 2002); migrants have continued to settle there ever since. New suburbs such as Keur Massar, located towards the outskirts of Dakar's built-up area, have been created more recently to house the growing population of the city. Today, numerous peripheral, generally low income, areas of the city make up the banlieues [suburbs] of Dakar, where a large proportion of urban dwellers live.

Women constitute 51 per cent of the population of Dakar (ANSD, 2013a,11). Just over one in three (34 per cent) of Dakar's households (and 39 per cent of households in other urban areas) are headed by women (ANSD, 2013a,13) (2). Around 15 per cent of all Dakar's households are headed by widows [ANSD, 2013a,14]), and overall one in three households affected by poverty in Dakar (31 per cent) is widow-headed (ANSD, 2013a,31). Just over a quarter of all Dakar's inhabitants - 26.1 per cent - are living in poverty (ANSD, 2013a,28).

At the time of the research, poor families were coping with the impact of the recent financial, fuel and food crises, and the aftermath of flooding in some suburbs (3), including Guèdiawaye and Yeumbeul. These low-lying areas of land were formerly used for market gardening and were not suitable for settlement, but following drought in the 1970s, people settled and built houses on the dry land. Such informal housing in cities often lacks adequate sanitation and other basic infrastructure, and is at risk of annual flooding during the rainy season.

In addition to these pressures, urban households in Dakar continue to take in and support recently-arrived rural relatives and acquaintances. Dakar region has the largest proportion of internal migrants (4) in the country, at 43 per cent (ANSD 2014, 262). Almost half of Dakar residents (44.9 per cent) are tenants living in rented accommodation (ANSD, 2013a, 17), over a third (36 per cent) have a land title and own their own homes, 11.3 per cent own their property but lack a title, while 4.5 per cent are accommodated by a relative or friend free of charge (ibid.).

The areas where this research was carried out are home to a ethnically diverse population of urban residents, many of whom work in the informal sector and are predominantly Muslim. The research focused on the Serer ethnic group, who represent 15 per cent of the Senegalese population and, alongside other minority ethnic groups such as the Hal Pulaaren and Diola,

(C) Ruth Evans 3/2/15. Article in press, Gender and Development, March 2015 issue, 'Working on Gender Issues in Urban Areas'. 
are significantly more likely to experience poverty (with an 83 per cent greater risk of living in poverty) than the Wolof, the largest ethnic group in Senegal (Fall et al., 2011). Previous studies have tended to focus predominantly on Wolof families, overlooking the experiences of the Serer and other minority ethnic groups, who often have culturally distinct inheritance practices (5) and as already noted, may be more at risk of poverty. The Serer live predominantly in the south-central and south-eastern parts of the groundnut (peanut) basin, long considered the "home of some of the most "traditional peasants" in the old French African Empire' (Galvan 2004,33), while also residing in Dakar and other urban areas. Serer men and women have long engaged in circular, seasonal, as well as more permanent migration to Dakar as an important survival strategy (Gadio and Rakowski, 1995). Serer women traditionally work in low income jobs in the informal sector as millet pounders, laveuses [laundry women] and as bonnes [maids/domestic workers] in the city. Serer young women often seek domestic work in the city during school vacations to pay for clothing and school expenses and may continue with full time work when they leave school, sending remittances to rural family members when they are able to (Evans, 2014; Delaunay and Enel, 2009).

\section{Women's rights, inheritance and legal pluralism in Senegal}

Although the majority of the population practise Sufi Islam, Senegal is a secular state (6). Islamic and Christian practices have mingled with traditional practices (Sow 2003). The Constitution, reformed most recently in 2001, provides many formal rights for women, including equality with men before the law and the right for women to control their own property (Scales-Trent 2010). Senegal is also a signatory to the UN Convention on the Elimination of all Forms of Discrimination against Women (CEDAW) and other international human rights conventions. However, Senegal has often failed to harmonise its national laws with the provisions mandated in international conventions (ibid).

The contradictions of legal pluralism and the 'triple heritage' of African, Islamic and colonial influences (Bass and Sow 2006) are particularly evident in relation to family law, inheritance and social protection policies in Senegal. The statutory Family Code, originally passed in 1973, is based on French law, and provides for the spouse and his/her male and female children to inherit equal shares of the inheritance. However, the Family Code notably accommodates polygamy, requiring men to choose between monogamy, polygamy with two, or polygamy with more than two wives, with a default rule whereby the marriage is considered polygamous if a husband fails to make a choice (Sow 2003; Scales-Trent 2010).

The Family Code includes special provision for Muslims to opt for Islamic law regarding the division of inherited assets. According to Islamic law, in the case of a death of a household head, Muslim daughters are entitled to only half of the estate that their brothers receive, and widows are entitled to only one-eight of their husband's estate. Other family members are also entitled to shares of the inheritance.

Because of its accommodation of Islamic elements, the Family Code has been the subject of much debate, criticism and lobbying for reform from religious leaders and women's rights proponents alike (Scales-Trent 2010). Fatou Kine Camara (2007) argues that although it was dubbed the 'Women's Code' and hailed as a 'triumph of modernity' over traditional custom, the Family Code 'only trades African matriarchy-based laws for patriarchal rules copied from French civil law and Algerian customs coloured by Muslim laws' (p.789). The reality is more

(C) Ruth Evans 3/2/15. Article in press, Gender and Development, March 2015 issue, 'Working on Gender Issues in Urban Areas'. 
complex than contrasting crude notions of modern progress versus backward tradition. The Family Code contains elements of French Civil Law which reflects the patriarchal origins of French law, and retains provisions important in Muslim traditions which are also patriarchal in nature. In contrast, the Senegalese customs which existed before colonialism (and which have evolved and are still practised today to some extent) varied according to ethnic group and reflect both patrilineal and matrilineal inheritance systems (Bass and Sow, 2006).

However, despite their gender-discriminatory nature, analysis of Demographic and Health Surveys reveals that inheritance practices may be more favourable for women in Senegal than in many other African countries. Indeed, 57 per cent of widows in Senegal reported inheriting assets compared to an average of 47 per cent across 15 sub-Saharan African countries (Peterman, 2012, 550). In Senegal, widows and/or their children inherited the majority of the assets, while on average in sub-Saharan Africa, the spouse's children/family inherited the majority of assets.

However, 14 per cent of widows reported that the husband had had no property, which is almost double the average ( 8 per cent) for the 15 Sub-Saharan African countries (Peterman, 2012 550).

\section{The research methods}

The research used qualitative methods to find out more about the experience of widows in relation to inheritance in the current context of legal pluralism.

Twenty families of Serer ethnicity were identified who had experienced an adult relative's death in recent years (7). In the urban locations, in-depth interviews were conducted with 13 members of 8 families affected by the death of a relative, comprising six widows, two widowers, three young women (all aged 27) whose fathers had died and two other family members. Five of the eight widows and widowers had had polygamous marriages, and all were Muslim, except for one Roman Catholic widow. A focus group was also conducted with four Muslim members (of Serer, Wolof and Toucouleur/Tukulor ethnicity) of a widows' association in Médina. Key informant interviews were conducted with an imam and a head of district (Chef du Quartier) in Guédiawaye, and with ten professionals working on poverty alleviation, women's and children's rights and development at national level or in Dakar (8).

Following preliminary analysis, two participatory feedback workshops were conducted with widows, widowers and orphaned young people in Guédiawaye to identify key messages for a short digital video that was discussed with policymakers, practitioners, participants and researchers in a seminar in Dakar in 2012. Quotations in this article have been translated into English by the author, and pseudonyms have been used to protect participants' anonymity.

\section{The findings: property inheritance, widowhood and poverty in Dakar}

Alongside a regular income, the inheritance and ownership of housing was identified by widows and widowers as a key means of ensuring financial and emotional security in urban areas. Housing was regarded as the main asset that enabled urban households to 'manage/cope' (se débrouiller) without having to worry about paying rent. For some families, property also provided an important source of income (through renting out rooms) which helped to meet the high living costs in Dakar. In the video, widows emphasised that if their

(C) Ruth Evans 3/2/15. Article in press, Gender and Development, March 2015 issue, 'Working on Gender Issues in Urban Areas'. 
housing costs were taken care of, they could meet their remaining living costs (food, clothing, water and electricity bills, children's schooling and healthcare and so on) themselves through their income-generation activities.

The significance of housing as the key heritable asset in urban areas contrasted with Serer rural communities, where agricultural land and livestock were regarded as the main source of intergenerational wealth transfer (author, forthcoming), and family homes headed by the eldest brother were not usually inherited by women. In addition, the costs of living were generally much lower in rural communities.

Some families living in urban areas associated poverty with their struggles to pay the rent and/or payments and debts for medical treatment. Some men lacked property or other assets in the city, although they had inherited land in rural areas. Widowers reported that their wives had few, if any, assets for their husband and children to inherit. One widower, for example, was a car mechanic, and reported that he worked seven days a week to support his young children (who lived with his mother in the village), to pay for his rented room in Guédiawaye and pay off debts owed to friends and neighbours incurred during his deceased wife's cancer treatment. An older widow's comments also reveal urban residents' frustrations with familial duties and expectations of rural relatives:

When you are in Dakar, your relatives think that you have everything, so they won't do anything for you, they think that if they come, you will give them everything anticipating God's will. They will bring you their children, while they don't even give you a franc. They harvest millet but they don't even think of giving you any.

(Interview, Guédiawaye, 13 October 2011)

Such familial responsibilities may put pressure on urban households that are already struggling to make ends meet in the low income suburbs.

Respondents rarely expressed their wishes for inheritance in a written or verbal will. In Muslim families, the inheritance of housing and other assets in urban areas was usually settled within families according to Islamic law, sometimes with reference to imams and other religious leaders and with little, if any, reference to the Family Code. This meant, as stated earlier, that children inherited most of the deceased's assets, and widows received a share. In Dakar, most of the widows interviewed (four out of six) and their children inherited housing or a financial share of their deceased husband's property, which helped to reduce the economic pressures on the household following their husband's death. The findings imply that life in the city is changing norms around inheritance; Serer Muslim families in Dakar are more likely to use Islamic legal principles when sharing out housing, financial assets and other resources after a death compared to rural areas.

Gnilane, one interviewee and her husband had been forced to sell their house in Guédiawaye and buy a plot and build a house in Keur Massar (a suburb where land was available at lower cost) (2) in order to pay for his medical costs during the three year period of ill health which culminated in his death. The house was still not finished and was located a considerable distance from the market in Guédiawaye, where Gnilane sold fish to support her five children. The move had significantly increased her transport costs each day and she had not yet had the time to develop support networks with neighbours:

(C) Ruth Evans 3/2/15. Article in press, Gender and Development, March 2015 issue, 'Working on Gender Issues in Urban Areas'. 
We live in difficulties, the struggle to cope [la débrouillardise] and other things, when you are taking care of the children, the problems of feeding them, the fact that we have only just come to live in the district recently is another difficulty, we don't know anyone here yet.

(Interview, Keur Massar, 27 October 2011)

However, Gnilane thought that owning their own house helped to prevent the family from descending further into poverty:

If we didn't have the house, things would get much worse, you understand the importance of the house for us.

(ibid).

An imam in Guédiawaye explained that if people were practising Muslims, it was assumed that on their death their assets would be shared according to Islamic law. This contrasted with rural areas, where land was usually inherited using Serer customary practices (author, forthcoming). In the research, two widows living in Dakar whose husbands had maintained a family home with other wives in rural areas said they were not considered to have any claim to assets owned in the village, although one widow's children had inherited small plots of their father's land and the son hoped to build property there in future.

In two polygamous households in Dakar, the value of the property was divided between cowives and their children. Although the widows inherited a share of housing, their husband's death nevertheless resulted in considerable material and social consequences.

\section{Mariama: flexible application of Islamic law}

In one family, the maternal uncle of each co-wife sought advice from the local imam about how to proceed with the division of assets according to Islamic law and discussed this with the widows, who were observing mourning rituals at the time. Through this process, it was agreed that Mariama, the widow interviewed, could remain in the conjugal house since she had eight children, while her co-wife left with her child to live with her mother in another city.

Despite the inheritance, Mariama was under considerable economic pressure; she did laundry for neighbours, and sold cooked food to earn a living, in addition to the small income gained from renting out the co-wife's former room $(15,000 \mathrm{~F}$ CFA per month, the equivalent of $£ 18$ ) and contributions from her daughters' incomes from domestic work, which they found exhausting (earning $£ 18.70$ and $£ 21$ per month). Mariama was only able to pay off the debt owed to her co-wife for her inherited share of the house gradually.

Mariama said she appreciated her co-wife's understanding in allowing the payment to be made over a period of several years. The application of Islamic law thus was flexible enough to recognise the circumstances of widows who may only be able to buy out a co-wife's share of the inherited property over an extended time period. Such practices however depended on goodwill, understanding and amicable relations between different co-wives and the relatives of each family.

Yacine: conflict with co-wives 
Some widows had experienced tensions and disputes with co-wives and their children over property and other assets that they expected to inherit from their husbands. Yacine, a Muslim widow living in Dakar whose husband had three other wives, two of whom lived in his natal village, had experienced conflict with her co-wives and their children over her husband's inheritance. Yacine's co-wives and their children had tried to force her to sell the house where she lived with her children in Dakar and divide the proceeds, despite the fact that she owned the house in her own right. The house had formerly belonged to her husband and the couple had lived there for many years. When he returned to live in the village with his other wives and wanted to sell the house, Yacine's younger brother had bought the house for her, so that she could continue living there with her children. The co-wives' and children's inheritance claim to the house was therefore unfounded.

Yacine's story highlights the likelihood of greater poverty among widows of polygamous marriages. Under Islamic law, women in polygamous unions inherit less than those in monogamous marriages, since the eighth share of the man's property which is allocated to a widow is divided among the wives and the shares allocated to children are divided among all the children of the deceased, with sons receiving twice the share that daughters received (interview, imam, Guédiawaye, 4 November 2011). In the focus group, widows highlighted the fact that it is usually the deceased's children rather than widows who directly inherit property, and hence it is difficult for widows in polygamous unions without children to secure their share of the inheritance. They also commented that wealthier members of the family sometimes bended the rules of Islamic inheritance to their own ends:

It [inheritance] is based on religion, but sometimes people modify the procedure. They don't do things normally or they even block some shares and the well off will distribute the assets among themselves and the weakest will lose out.

(Focus group, Médina, 11 November 2011)

A community worker also commented that the brother of the deceased or other male relatives responsible for dividing inherited assets sometimes forged or modified paperwork, such as title deeds, for their own benefit. Women with low levels of literacy were particularly vulnerable to this form of exploitation.

An imam justified the fact that daughters received half the inherited share that sons in similar positions would inherit from their father by referring to other aspects of Islamic law that specified that a wife is entitled to maintenance from her husband, in terms of shelter, clothing, food and medical care (UN-Habitat, 2005):

...in Shari'a [law], the girl [daughter of the deceased] will not take care of a family, but she is taken care of, in contrast to the boy [son of the deceased] who will maintain the family with this money. As for the girl, she will keep her money even if she is married, she will leave with her money to do what she wants with it because it's up to her husband to pay for everything for her in the household. So with the division [of inherited assets], you see that the girl profits more than the boy because the girl will keep her money, while the boy is constrained by having to maintain his family

(Interview, Guédiawaye, 4 November 2011).

(C) Ruth Evans 3/2/15. Article in press, Gender and Development, March 2015 issue, 'Working on Gender Issues in Urban Areas'. 
Although women may contribute to the costs of supporting the family, the imam emphasised that a wife was not obliged to provide financial support under Islamic law. Fatou Kiné Camara (2007) argues that indigenous socio-cultural values in Senegal train girls and women to be economically independent of their husbands, and consequently they often have their own financial resources and property such as furniture and jewellery. The Family Code directly contradicts such customary practices and religious law, since the Code mandates that women have a duty to provide for their siblings and parents in need and to contribute to the home and family maintenance (Camara 2007).

Despite inheriting a share of their deceased husband's property and financial assets (if they had any) and/or owning property, many widows experienced chronic poverty. The death of a husband was often associated with a significant change in material circumstances. Widows usually became the main breadwinners, alongside relying on remittances from adult children and income from young people's paid work. For some widows living in non-cohabiting polygamous unions, however, the death of their husband had not resulted in any significant changes in their material circumstances, since they had maintained independent households during their husband's lifetime.

Widows developed a range of strategies to manage economic pressures, including: renting out rooms, participating in women's co-operatives and associations, which provided access to credit, and engaging in small business activities in the informal sector. One widow received regular income from her husband's pension every two months. Many participants commented on the high level of community solidarity and reciprocity among extended family members, neighbours and religious leaders, but material or financial support to widows and their children was often limited.

In the video produced with participants, widows in Dakar emphasised how important the inheritance and ownership of property was in alleviating the financial pressures they faced and identified the need for good quality housing for poor widows as their key priority for policymakers and practitioners. While some financial assistance was available to the poorest families through the Ministry of Social Action, professionals commented that the support provided was often minimal, was only available as a one-off grant, and could be delayed or diverted. As one community health worker commented: 'it's just one-off assistance. You eat that and it's finished' (Interview, Guédiawaye, 9 November 2011).

Widows participating in the focus group had received some assistance through the local Centre de Promotion et de Réinsertion Sociale (under the Ministry of Social Action), which they valued. The short-term nature of the support, however, had led to the widows' decision to organise themselves into an association that operated a rotating credit and savings scheme. None of the widows or widowers interviewed had benefited from state or NGO support following the death of their spouse. Some commented that any support available usually only benefited those who had connections to local officials in positions of power.

Working on inheritance, poverty alleviation and social protection in the city in the context of legal pluralism

Some women's rights organisations provided free legal advice, support and advocacy for women and young people in pursuing inheritance claims. Listening centres or law shops (boutiques de droit) in low income neighbourhoods of Dakar (AJS) and Kaolack (APROFES) as well as the training and provision of legal experts across municipal areas (AFEME) enabled widows and others to access legal consultations and assistance with inheritance

(C) Ruth Evans 3/2/15. Article in press, Gender and Development, March 2015 issue, 'Working on Gender Issues in Urban Areas'. 
disputes, gender-based violence and other discriminatory practices. In contrast, some childfocused organisations had little knowledge of legal issues or religious or customary practices surrounding asset inheritance.

While all of the professionals interviewed in the research considered that the Family Code was appropriate generally in protecting widows and orphans in Senegal, they highlighted the fact that laws were often not applied. Low levels of education and literacy and a lack of knowledge about women's rights and how to claim these were identified as major barriers by women's rights organisations. In Senegal as a whole, adult literacy rates are only 40 per cent among women compared to 66 per cent for men, although rates are considerably higher in urban areas of Dakar (59\% for women and 80\% for men: ANSD, 2013a,46).

Other barriers to pursuing legal inheritance claims identified by AJS and AFEME included: a lack of money to pay for legal services (a lawyer's fees are often in excess of 200,000 CFA, equivalent to $£ 240$, beyond the means of many); a lack of documents needed to pursue cases through the courts, such as marriage certificates, property deeds and land use titles; and a reluctance for a widow to take her in-law's family or other relatives to court due to a fear of social condemnation and causing conflict. A leader of one women's organisation explained:

Here, you should not, for example, drag your husband, the family of your in-laws to court, it's seen badly [...] it's paradoxical, since there is a law which protects everyone, I believe that women should not stay bound. At the moment, they are fearful, so it's a situation of last resort, if you talk about the law, it's because there's no other solution, no possibility and you appeal to the law, but as long as there is a possibility of reconciliation, of negotiation, it's much better to do it within the family, negotiate so that you don't have to take legal action (Interview, Médina, 29 October 2011).

Fatou Kiné Camara (2007) argues that going to court to settle a marital dispute is regarded as an unforgivable offence. Invoking an adversarial legal system is completely contrary to customary practices in Senegal, which are based on a process of mediation, negotiation and counselling, led by family elders.

However, the ideals underpinning customary practices are critiqued by women's rights activists, and it is possible that contemporary life in the city is creating tensions which make it even less likely that women's interests as individuals can be met. Some professionals from government ministries and NGOs felt that polygamy was increasingly incompatible with urban lifestyles and that jealousies between co-wives were becoming more evident as urbanisation continued. Many professionals and community members thought that inheritance disputes were more likely in urban areas, especially in polygamous marriages when the husband had significant assets to be divided between co-wives and their children. A representative of $A J S$ acknowledged that co-wives with the largest number of adult sons would generally gain most from the division of inherited assets under Islamic law, while cowives with daughters or fewer or no children could lose out. Younger co-wives could also be disadvantaged compared to older co-wives, especially if they were the same age or younger than the eldest children of the first wife.

The different positions of co-wives may lead to disagreements on whether Islamic law or common law should be applied. In disputed inheritance cases of a deceased Muslim, the judge decides whether Islamic or common law should be applied, on the basis of whether the deceased had been a practising Muslim, while also taking into account the heirs' wishes.

(C) Ruth Evans 3/2/15. Article in press, Gender and Development, March 2015 issue, 'Working on Gender Issues in Urban Areas'. 
Imams and NGOs providing legal advice commented that inheritance disputes were not confined to polygamous unions; they also sometimes emerged when a brother or sister of the deceased wanted to appropriate all of their relative's property to the exclusion of other heirs, and disputes were found in Catholic as well as Muslim families.

AJS saw one of their greatest successes as raising awareness of women's rights and popularising the law through workshops, training and collaborations with community groups. The organisation had also successfully lobbied for legal reforms to improve women's status regarding employment, social equality and nationality laws and the Family Code, working in collaboration with the Ministry of Justice. Such efforts had recently resulted in the harmonisation of the age of marriage for girls and boys at 18 years of age - raising it from the former age of 16 years for girls.

Women's rights organisations commented, however, that more awareness-raising activities were needed to improve knowledge and understanding of women's and children's legal rights and to increase the accessibility of statutory law to the public by translating legal information from French into Wolof and other local languages. Fatou Kiné Camara (2007) observes that the majority of the population remain unaware of the Family Code and other laws, since 90 percent of the population do not even speak French.

A shared view among the professionals working for child-focused organisations who participated in the research was that while ownership of property and a regular income were important, human capital, such as having the education, skills and knowledge to develop sustainable livelihoods, was also necessary to interrupt poverty cycles. Improving girls' access to education and investing in early childhood was seen by many of these professionals as an effective way to prevent the intergenerational transmission of poverty.

Some professionals identified a need to harmonise the plural legal systems and saw these contradictions as a major barrier to the development of a social protection system:

We're not too strong yet on protection, everyone's struggling with protection[...]. That's because [...] there are mutually exclusive systems, one introduced by the French system and one informed by religion and custom[which make protection] very difficult to implement".

(Interview, Representative of a child-focused organisation, Guédiawaye, 9 November 2011)

This interviewee regarded community and religious leaders and government as playing an important role in trying to reconcile the formal legal and education systems with customary law and social norms to ensure the protection of women and children: 'They can step towards each other and say, "how can we make our two systems co-exist and not [be] mutually exclusive?"' (ibid). Similarly, representatives of women's rights organisations commented that the resistance of religious leaders to the promotion of gender equality in matters of inheritance, alongside engrained cultural practices and beliefs, such as early marriage and female genital cutting, could be major barriers to their work.

In addition to the contradictions posed by legal pluralism, several NGO, UNICEF and government representatives identified wider challenges of working on poverty alleviation in urban areas. These related to tensions between government, NGOs and donors, such as a lack of co-ordination and competition between partners and donors at national and local levels; lack of government support and political will to engage with NGO partners; the unstable, 
temporary nature of government ministries; donor restrictions on the development of new activities to meet identified needs; and a reliance on NGOs to fill gaps in state provision of basic services. Further concerns focused on insufficient funding, poor governance in targeting assistance to the most vulnerable groups and a lack of community engagement.

A UNICEF representative noted that inequalities in access to services and opportunities in Dakar and other regions were growing and was concerned this would lead to increased ruralto-urban migration, placing further pressure on extended family households in the low income suburbs of Dakar. Meanwhile, NGOs such as Plan International and Synergy for Childhood commented that large donors were reluctant to support local and national NGOs working on health, hygiene and sanitation, nutrition and other issues in Dakar, due to assumptions that access to healthcare and basic services is better in the capital than in rural areas. Such assumptions overlooked the overcrowded living conditions and poverty of households in the suburbs, where chronic illnesses such as TB were common, and poor sewage and sanitation infrastructure caused major problems in low income urban areas, such as Guédiawaye, which were at risk of annual flooding.

\section{Conclusion}

This article has highlighted the complexities of working on poverty alleviation and the social protection of women and children in the context of legal pluralism in urban Senegal.

In practice, most widows interviewed inherited a share of their deceased husband's property (in the case of polygamous marriages), or owned property in their own right in urban areas. In Muslim families, the process of sharing the deceased's assets according to Islamic law was usually led by male relatives, sometimes in consultation with an imam. Such inheritance practices contrasted to Serer rural areas, where land was usually inherited by the eldest son and other male relatives according to customary practices and the family home was not divided, valued or sold, but passed on to brothers and sons. Property inheritance and ownership reduced financial pressures in urban areas and, alongside widows' own income generation activities and remittances from children, enabled them to meet the remaining household expenses and pay for children's education, nutrition and healthcare.

However, the research found that women in polygamous unions, especially those with low levels of literacy and education and who do not have access to legal support and advice, may lose out in asset inheritance. Widows occupy differential legal and social positions in safeguarding property inheritance, depending on their marital position, their religion, ethnicity, education and literacy, the gender of their children, relations with co-wives and inlaws, and other social ties and support networks they are able to draw on.

The efforts of women's rights organisations to advocate for women's legal rights to property inheritance among religious and local leaders, government and other stakeholders, to raise awareness of women's and girls' property rights and to foster women's and girls' economic autonomy and social and political participation seem to offer the best means of tackling gender discriminatory religious and customary inheritance practices in the city. However, such efforts are likely to be met by considerable resistance from powerful actors, such as male local and religious leaders, who may see themselves as the 'guardians' of religion/culture, although women's organisations' recent involvement of religious leaders in initiatives to increase women's access to land in rural areas of Senegal suggests that they may be open to dialogue. Further challenges may relate to NGOs' and governmental agencies' reluctance to become involved in contentious religious, legal or 'family' matters associated 
with the 'private' sphere. This highlights the importance of the demand for gender equality coming from Senegalese women and girls themselves.

While professionals regarded the legal framework in Senegal as generally appropriate in safeguarding women's inheritance rights and/or appeared hesitant to criticise Islamic law, legal pluralism does create confusion, and its implementation reveals several material, social and cultural barriers to women's access to legal justice. These include low levels of awareness of and inaccessibility of laws codified in French, continuing gender disparities in educational levels and literacy rates, the costs of legal services, lack of necessary documentation and a strong socio-cultural preference for conflict resolution through family mediation processes rather than through an individualistic adversarial legal process. Gender discriminatory barriers built into the legal framework often result in unequal outcomes for women, even when property laws guarantee equal rights (UN Women, 2011).

In order to safeguard women's and girls' inheritance rights, address some of the tensions and contradictions caused by legal pluralism and to alleviate poverty in urban areas, a number of policies and practices are needed, including:

- Support for family mediation with relatives and religious leaders, free legal advice and advocacy for women and young people to pursue inheritance claims;

- Efforts to harmonise national laws with the Constitution and international human rights conventions such as CEDAW;

- Raising awareness about women's and children's rights and working with government and community and religious leaders to tackle gender discrimination in inheritance and other issues;

- Improving the quality of education and prioritising girls' access to education;

- Social protection measures targeted effectively towards poor widows and orphaned children, such as cash transfers to pay for basic needs (food, healthcare, schooling and housing);

- Credit and savings initiatives targeted to women and young people, alongside training and capacity-building, to promote small business activities and sustainable livelihoods in cities and urban spaces.

The approach adopted by AFEME and other community-based women's organisations to develop networks of grassroots women's groups or 'cells' across districts in the city seems to offer considerable promise in fostering women's and girls' collective mobilisation, leadership skills and greater economic, social and political participation to tackle gender inequalities at all levels of society.

Finally, a focus on inheritance and the importance of property ownership is only a part of the picture. Other factors, particularly mothers' educational background, investments in the younger generation, and support networks, may be just as important, if not more so, in alleviating poverty and reducing social inequality than the inheritance of assets such as housing (Lambert et al., 2011; Fall et al., 2011). This demonstrates the importance of a contextual analysis of women's and children's legal rights and the diverse situation of widows, orphaned children and other 'vulnerable groups' in complex urban environments.

\section{Acknowledgements}

I wish to thank all the family members, religious and community leaders and professionals who so willingly shared their experiences and views. I am very grateful to Baba Sarr, Fatou Kébé, Prosper Diene Faye, Laurie Marie for their research and translation assistance and to Khady Sarr, Yacine Diagne, Prof. Abdou Salam Fall and Ian Hopwood for facilitating access 
to participants. I am also grateful to the University of Reading and Walker Institute for Climate System Research for funding the research.

\section{Ruth Evans is an Associate Professor in Human Geography, Department of Geography \& Environmental Science, University of Reading, Whiteknights PO Box 227, Reading RG6 6AB, UK. Email: r.evans@ reading.ac.uk.}

\section{Endnotes}

1. The research was funded by the University of Reading and Walker Institute for Climate System Research. Ethical approval for the research was granted by the University of Reading Research Ethics Committee in 2011 and 2012.

2. Women in Dakar have a relatively low fertility rate (3.7 children per woman) compared to the national rate (5.1 children per woman) and urban areas in general (4.1 children per woman) (ANSD, 2014,169). While women in urban areas in Senegal (and elsewhere in Sub-Saharan Africa and globally) generally have fewer children than those living in rural areas, poor women living in cities have limited access to reproductive health care and unmet contraception needs. Indeed, UNFPA $(2007,23)$ suggests that at times the reproductive health situation of poor women in cities more closely resembles that of rural women and poverty may be a better indicator of fertility patterns than rural or urban residence.

3. Environmental pressures in rural and urban areas are likely to be exacerbated by climate change in future (Toulmin 2009). Dakar and other coastal cities and settlements of West Africa will be highly vulnerable to the impacts of projected sea level rise, leading to great losses of coastal land by erosion and submergence, alongside increased salinisation (UN-Habitat 2014).

4. Internal migrants are defined by $\operatorname{ANSD}(2014,222)$ as those whose place of origin and place of destination are located within the country's territory.

5. The Serer adopted Islam and Catholicism during the 20th century, later than most other ethnic groups in Senegal (Bass and Sow, 2006). Traditionally, the Serer observe aspects of both patrilineal and matrilineal inheritance systems for the transfer of wealth, values and knowledge between generations. Serer customary practices regarded women as having little claim to land ownership, and the family home was not usually divided, but was inherited by brothers and sons of the deceased (Evans, forthcoming). Polygamy is slightly less common among the Serer than other ethnic groups in Senegal (Bass and Sow, 2006).

6. The vast majority of the population (94 per cent) are Muslim, while a minority are Christian (4 per cent) and animists and other religions ( 2 per cent) (ANSD 2013b,2).

7. These families were identified with the help of NGO staff and key contacts in each community, either directly or using snowballing (that is, following up suggestions from initial contacts to talk to others whom they knew).

8. These included UNICEF, NGOs and community-based organisations (including Association of Senegalese Women Lawyers (Association des Juristes Sénégalaises [AJS], Plan International, Synergy for Childhood [Synergie pour L'enfance], Association of Women of Médina, Dakar [AFEME], Association for the Promotion of Senegalese Women [APROFES]) and representatives of the Ministry of the Family and Ministry of the Economy and Finance. 


\section{References}

Agence Nationale de Statistique et de la Démographie (ANSD) (2014) Recensement Général de la Population et de l'Habitat, de l'Agriculture et de l'Elevage 2013, Rapport Définitif.

Dakar: ANSD and Ministère de l'Economie, des Finances et du Plan, République du Sénégal.

ANSD (2013a) Deuxième Enquête de la Suivi de la Pauvreté au Sénégal (ESPS II 2011). Rapport Définitif. Dakar: Ministère de l'Economie et des Finances, République du Sénégal.

ANSD (2013b) Enquête Démographique et de Santé Continue au Sénégal (EDS-Continue) 2012-2013, Rapport final 1ère année. Dakar: ANSD, Calverton, Maryland: MEASURE DHS, ICF International.

Bass, Loretta and Sow, Fatou (2006) 'Senegalese families: the confluence of ethnicity, history and social change', in Oheneba-Sakyi, Yaw and Takyi, Baffour (Eds.), African Families at the Turn of the $21^{\text {st }}$ Century, Westport: Praeger Publishers, pp.83-102.

Camara, Fatou Kiné (2007) 'Women and the Law: A Critique of Senegalese Family Law', Social Identities, 13, 787-800.

Chant, Sylvia (2013) 'Cities through a "gender lens": a golden "urban age" for women in the global South?', Environment and Urbanization, 25(1): 9-29.

Cooper, Elizabeth (2012) 'Women and inheritance in Sub-Saharan Africa: what can change?', Development Policy Review 30(5): 641-657.

Delaunay, Valerie and Enel, C. (2009) 'Les migrations saisonnières féminines: le cas des jeunes bonnes à Dakar', in Vallin, J. (Ed.) Du Genre et de l'Afrique, Paris: INED, pp.389402.

Evans, Ruth (2014) 'Parental death as a vital conjuncture? Intergenerational care and responsibility following bereavement in Senegal', Social and Cultural Geography, 15(5): 547-570.

Evans, Ruth (forthcoming) Gendered Struggles over Land: Shifting Inheritance Practices among the Serer in rural Senegal, Gender, Place and Culture (under review).

Fall, Abdou Salam, Antoine, Philippe, Cissé, Rokhaya, Dramani, Latif, Sall, Mohamadou, Ndoye, Tidiane, Diop, Mody, Doucouré, Bakary, Sylla, Momar Ballé, Ngom, Papa, Faye, Abdoulaye (2011) The Dynamics of Poverty in Senegal: Chronic Poverty, Transitional Poverty and Vulnerabilities, Policy Brief, LARTES National Studies No.27, January 2011.

Gadio, Coumba Mar and Rakowski, Cathy (1995) 'Survival or empowerment? Crisis and temporary migration among the Serer millet pounders of Senegal', Women's Studies International Forum, 18( 4): 431-443.

Galvan, Dennis (2004) The State must be our Master of Fire. How Peasants Craft Culturally Sustainable Development in Senegal. Berkeley and Los Angeles: University of California Press. 
Lambert, Sylvie, Ravallion, Martin and van de Walle, Dominique (2011) 'Is it what you inherited or what you learnt? Intergenerational linkage and interpersonal inequality in Senegal', Policy Research Working Paper 5658, The World Bank Development Research Group and Poverty Reduction and Economic Management Network Gender Group, May 2011.

Payne, Geoffrey, Durand-Lasserve, Alain, Rakodi, Carole (2008) 'Social and economic impacts of land titling programmes in urban and peri-urban areas: international experience and case studies of Senegal and South Africa'. Final Report submitted to Government of Norway, Swedish International Development Agency and UN-Habitat.

Peterman, Amber (2012) 'Widowhood and asset inheritance in Sub-Saharan Africa: empirical evidence from 15 countries', Development Policy Review, 30(5):543-571.

Piga, Adriana (2002) '3. Processus socioculturels dans la ville de Dakar: politique urbaine, immigration et secteur informel', in Adriana Piga, Dakar et les Ordres Soufis. Processus socioculturels et développement urbain au Sénégal contemporain, Paris: L'Harmattan; pp.285-412.

Quisumbing, Agnes (2007) 'Investments, bequests and public policy: intergenerational transfers and the escape from poverty', Chronic Poverty Research Centre Working Paper 98, CPRC.

Scales-Trent, Judy (2010) 'Women lawyers, women's rights in Senegal: the Association of Senegalese Women Lawyers', Human Rights Quarterly 32: 115-143.

Sow, Fatou (2003) 'Fundamentalisms, globalisation and women's human rights in Senegal', Gender and Development 11(1): 69-76.

Toulmin, Camilla (2009)Climate Change in Africa. London: Zed Books.

United Nations Fund for Population Activities (UNFPA) (2007), State of the World's Population 2007: Unleashing the Potential of Urban Growth, UNFPA, New York, http://www.unfpa.org/sites/default/files/pub-pdf/695_filename_sowp2007_eng.pdf [accessed $21 / 01 / 15]$.

UN-Habitat (2005) Paper 6: Islamic Inheritance Laws and Systems. Islam, land and property research series. Nairobi: United Nations Human Settlements Programme (UN-Habitat).

UN-Habitat (2014) The State of African Cities 2014. Reimagining Sustainable Urban Transitions. Nairobi: United Nations Human Settlements Programme (UN-Habitat).

UNICEF (2009) La Protection Sociale des Enfants en Afrique de l'Ouest et du Centre. Etude de cas du Sénégal. UNICEF.

UN Women (2011) In Pursuit of Justice. Progress in the World's Women 2011-12. UN Women. http://progress.unwomen.org/pdfs/EN-Report-Progress.pdf [accessed 23/01/15]. 